\title{
AN INTEGRATIVE WAY OF TEACHING MOLECULAR CELL BIOLOGY AND PROTEIN CHEMISTRY USING ACTIN IMMOBILIZATION ON CHITIN FOR PURIFYING MYOSIN II.
}

\author{
Souza, M.G. ${ }^{1}$, Grossi, A.L ${ }^{1}$, Pereira, E.L.B. ${ }^{1}$, Cruz, C.O. ${ }^{1}$, Mendes, F.M. ${ }^{1}$, Cameron, \\ L.C. ${ }^{1,2,3,{ }^{*}}$ and Paiva, C.L.A. ${ }^{1,{ }^{*}}$ \\ ${ }^{1}$ Laboratório de Bioquímica de Proteínas, UNIGEN, UNIRIO and ${ }^{2}$ Universidade \\ Castelo Branco, Rio de Janeiro, RJ.; ${ }^{3}$ UFU, Uberlâ ndia, MG, Brazil. \\ *Made equal contribution to this poster.
}

Our intent is to present our experience on teaching Molecular Cell Biology and Protein Chemistry at UNIRIO through an innovative approach that includes myosin II extraction and purification. We took advantage of the properties of muscle contraction and propose a simple method for purifying myosin II by affinity chromatography. This original method is based on the preparation of an affinity column containing actin molecules covalently bound to chitin particles. We propose a three-week syllabus that includes lectures and bench experimental work. The syllabus favors the active learning of protein extraction and purification, as well as, of scientific concepts such as muscle contraction, cytoskeleton structure and its importance for the living cell. It also promotes the learning of the biotechnological applications of chitin and the applications of protein immobilization in different industrial fields. Furthermore, the activities also target the development of laboratorial technical abilities, the development of problem solving skills and the ability to write up a scientific report following the model of a scientific article. It is very important to mention that this syllabus can be used even in places where a facility such as ultra-centrifugation is lacking. 